\title{
Education, Aspiration and aage badhna: The Role of Schooling in Facilitating 'Forward Movement' in Rural Chhattisgarh, India
}

\section{Arshima Champa Dost ${ }^{1}\left[\right.$ ] Peggy Froerer $^{2}$}

Accepted: 17 November 2020 / Published online: 22 January 2021

(c) The Author(s) 2021

\begin{abstract}
This article explores the role of education in marginalised young people's aspirations for aage badhna (forward movement). Drawing on ethnographic research in rural Chhattisgarh, central India, we show how young people's orientations toward a desired future remain anchored in education, even when possibilities for education-related forward movement become unattainable. The way in which aspirations are translated into locally viable outcomes, we suggest, is inextricably linked to the structural limitations that prevent access to education's more expansive opportunities and that underpin the possibility of falling behind. Focusing on how young people and their parents navigate this tension, we examine their attachment to the idea that education is necessary to get ahead, even as they fail to access its promised benefits. We suggest that a relational approach is critical to this understanding and argue that the way in which young people frame (and reframe) their aspirations must be understood in relation to both peers and parents, but also in relation to the central role that education plays in viable alternative pathways.
\end{abstract}

Keywords Rural education · Schooling $\cdot$ Aspiration $\cdot$ Relational $\cdot$ Tribal $\cdot$ Forward movement

\section{Resumé}

Cet article explore le rôle que l'éducation joue dans les aspirations de jeunes marginalisés à aller de l'avant (aage badhna). En s'appuyant sur une recherche ethnographique dans le Chhattisgarh rural, en Inde centrale, nous montrons comment l'orientation des jeunes vers un avenir souhaité reste ancrée dans la scolarité, même lorsque les

Arshima Champa Dost

arshima@gmail.com

Peggy Froerer

peggy.froerer@brunel.ac.uk

1 Independent Researcher, Musapur, Bihar, India

2 Brunel University London, Kingston Lane, Uxbridge, Middlesex UB8 3PH, UK 
possibilités d'accès à un avancement social, par l'éducation, sont hors d'atteinte. Selon nous, la manière dont les aspirations se traduisent en résultats viables au niveau local est inextricablement liée aux limitations structurelles qui empêchent l'accès aux opportunités plus grandes offertes par l'éducation et qui sous-tendent la possibilité de prendre du retard. En nous concentrant sur la façon dont les jeunes et leurs parents gèrent cette tension, nous examinons leur attachement à l'idée que faire des études est nécessaire pour avancer socialement, quand bien même ils ne parviennent pas à accéder aux avantages escomptés. Nous suggérons qu'une approche relationnelle est essentielle pour comprendre cette problématique, et soutenons que la manière dont les jeunes formulent (et reformulent) leurs aspirations doit être comprise à la fois en relation avec leurs pairs et leurs parents, mais aussi en relation avec le rôle central que la scolarité joue dans d'autres parcours viables.

\section{Introduction}

Radhika $^{1}$ is a 17 -year-old girl in Ichhapur, a predominantly adivasi (tribal) village of 400 inhabitants located in Chhattisgarh, central India. While peeling raw mangoes on the floor of her house one day, Radhika told the first author about her ideas of success. 'A successful person is someone who lives for what is good. They work hard, and keep getting ahead... The most intelligent pay attention to their work... and move forward (aage badhna).' The goal of forward movement, Radhika suggested, was to 'become someone' who had increased their knowledge and skills, could travel to more places, acquire more material things, and do more good for society than previously possible. In other words, aage badhna implied growth or 'getting ahead' in multiple dimensions-intellectual, economic, social and spatial. Determined to fulfil this goal, Radhika cycled $6 \mathrm{~km}$ to her secondary school every day. For many rural school-going youth like her, education is obviously necessary for aage badhna. As she put it, 'if school wasn't there, how would you develop the mind?'

This ethnographic vignette draws attention to the theme of our paper: the relationship between marginalised young people's aspirations and the opportunities made possible by education for different forms of aage badhna. The idea of 'forward movement' or 'getting ahead' was used routinely by young people and adults in rural Chhattisgarh in relation to schooling, to express aspirations for a 'better future'. It also came up in conversations with urban-based residents and policy makers elsewhere in Chhattisgarh and New Delhi, suggesting the ubiquity of this idea across India. Such notions are implicit in development discourses around the transformative potential of formal education (Kumar 2015; Drèze and Sen 2014; MHRD GoI 2020), hailed by academics and policy makers to be intrinsically beneficial for India's deprived population, providing the opportunities to 'get ahead' and

1 All personal/place names (except Chhattisgarh) are anonymised.

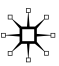


resulting, ideally, in naukri, or secure, salaried employment. ${ }^{2}$ The lack of education, or 'school-less-ness' (Jayaraj and Subramanian 2007, p. 188), in contrast, is thought to diminish livelihood opportunities and perpetuate poverty. Such discourses 'reify' (Jakimow 2016, p. 26) education by encouraging marginalised people to buy into its promises, and have been criticised by researchers for ignoring the conditions and complexities of poverty that lead to ongoing educational deprivation (Vasavi 2003), and for 'naturalising' formal schooling as the solution for a better future (Hopkins and Sriprakash 2015, p. 11). ${ }^{3}$

Discourses surrounding education's transformative potential have also found their way into research on aspiration (see for example Frye 2012; Camfield 2011; Stahl 2015; Morrow 2013). This concept refers to hopes, desires or dreams which, like Radhika's, are often 'multidimensional and many-faceted' (Ibrahim 2011, p. 4), envisioning notions of the 'good life' (Fischer 2014, p. xi). In line with these ideas, which are more substantively unpacked in the Introduction to this Special Issue (Huijsmans et al. 2020), we take aspiration to mean an orientation towards a desired future.

In further dialogue with the objectives of this Special Issue, we also explore how aspirations for getting ahead are constituted relationally (Huijsmans et al. 2014; Huijsmans 2016), produced in the 'thick of social life' (Appadurai 2004, p. 68) and shaped through interaction with (and relative to) others: namely peers and parents, but also in relation to the discourses surrounding the transformative potential of education and in terms of more pragmatic and viable possibilities towards a better future. We argue that the idea of aage badhna, which we regard as both a process through which aspirations can be achieved and an aspiration in itself, is inextricably linked to the very real possibility of 'falling behind' (peecche rehna). As highlighted in the Introduction to this Special Issue (Huijsmans et al. 2020), this 'relational' perspective underscores the importance of the social relations within which young people's agency is situated and through which their aspirations are formed and transformed, as they become more or less attainable.

The ways in which young people's aspirations are produced relationally, moreover, must also account for their structural marginality. As illustrated above, education is held by young people like Radhika to be necessary to avail of the opportunities and benefits that would enable her to 'become someone' ideally with secure, salaried employment (naukri) who can avail of a wider range of opportunities. However, the paper shows how such aspirations are complicated by structural disadvantages that impede successful engagement with these 'schooled ideals' (Balagopalan 2005), drawing attention to how young people and their parents navigate this tension, as they recognise that the promises associated with education are rarely attainable for them.

\footnotetext{
${ }^{2}$ Such discourses are rooted in the colonial project of education, with 'forward progress' linked to government employment. Education thus served social and moral functions, distinguishing the upper-caste elite from the uneducated masses, thereby reinforcing a sense of moral and social superiority and advantage which continues to this day (Kumar 2015, p. 39; Balagopalan 2003, pp. 58-60).

3 For more extended criticisms of the transformative potential of schooling, see Balagopalan (2014), Majumdar and Mooij (2011), Jha and Jhingran (2005), Chopra and Jeffery (2005).
} 
We thus contribute to the significant corpus of work in India concerning how structural conditions diminish the education-related potential for marginalised villagers to get ahead (see Morarji 2016; Balagopalan 2003, 2014; Jeffrey 2010; Jeffrey et al. 2010). While we engage further with some of these studies below, our research has specific resonance with Jakimow's (2016) work in rural Telangana, in relation to how investments in education sit alongside ideas that education-based aspirations are all but impossible. Jakimow's observations about how education provokes aspirations that are 'not objectively realizable' (ibid, p. 21) are especially apt. Drawing on Berlant (2011), Jakimow focuses on the consequences of hope and desire that underpin rural people's continued attachment to the powerful idea that education is the principal means of achieving the 'good life'. While marginalised agrarian labourers are aware of the 'improbability' that education will be enough to get ahead (2016, p. 11), Jakimow observes that it is precisely this 'almost impossibility' that underpins their commitment to education. Compounded by the absence of alternative routes to the 'good life', moreover, it is the attachment to this 'almost impossibility' that lowers their expectations and gives rise to the negative consequences that seemingly reinforce their structural positions of marginality (ibid, pp. 26-27).

In the pages that follow, we extend Jakimow's analysis to consider an alternative way in which education-related aspirations are framed, focusing on some of the ways in which young people re-frame their education-related aspirations into more viable possibilities. We also draw loosely on insights from Berlant (2011), whose notion of 'cruel optimism' helps us to understand those negative consequences that emerge from continued attachments to an 'object of desire' (Berlant 2011, pp. 23-24). In rural Chhattisgarh, this 'object of desire' refers to a particular kind of future (naukri), which is inextricably attached to the kind of educational success that few rural youth will be able to access (Ansell et al. 2020). What is seemingly 'cruel' about such attachments is that their 'near impossibility' evokes an even greater desire for them (cf. Jakimow 2016, p. 26). To abandon belief in the potential of education, however slim the possibility that this will lead to naukri, is thus to give up all hope of a better future.

Taking this analysis forward, we are interested in the different and more constructive ways that young people understand and act upon this educational potential in response to its inaccessibility. In doing so, we show how aspirations for 'forward movement' remain strongly related to schooling, even as they become oriented around more accessible possibilities. Like rural labourers in Telangana, villagers in Chhattisgarh are aware of the 'false promise' (Brown et al. 2011) associated with education (cf. Morarji 2016; Morrow 2013). Instead of giving rise to important opportunities for social mobility, for example, we show how schooling leads to a narrowing of young people's aspirations by progressively channelling 'forward movement' toward a limited set of occupations that are not achievable for most villagers. Notwithstanding this narrowing process, we argue that ideas of 'moving forward', which remain rooted in education, continue to shape the way in which young people re-frame their aspirations into alternative, more locally viable futures, even after schooling has been abandoned or when 
possibilities for education-related forward movement (naukri) have become unattainable.

\section{Research Context}

The study involved 9 months of ethnographic research in rural Chhattisgarh in 2016-2017. Rich in natural resources and notable for its steel and electricity industries, Chhattisgarh nonetheless is one's of India's poorest states, with $40 \%$ of its population classified as BPL or 'below poverty line' (Reserve Bank of India 2013). Nearly $78 \%$ of its population of 29 million lives in rural areas and over one-third is classified as adivasi ('Scheduled Tribe' ${ }^{4}$ ) — the vast majority of whom are BPL, relying on subsistence agriculture and selling forest produce for their livelihoods (Census of India 2011). High rates of poverty impact infant mortality, malnutrition and educational engagement (Sarvalingam and Sivakumar 2004). ${ }^{5}$ The rural adult literacy rate was $66 \%$, compared with $84.05 \%$ for urban Chhattisgarh (Census of India 2011) — in spite of large-scale programmes aimed at facilitating educational access (cf. Subrahmaniam 2005). ${ }^{6}$

During fieldwork, the first author stayed in the block capital, one of five subdivisions of the district with a population of $2300,70 \mathrm{~km}$ away from the district capital. She spent the first 3 months in two villages: Ashapur $(3 \mathrm{~km}$ from block, population 1200) and Icchapur (6 km from block, population 400), where she met Radhika. These villages were 85-90\% adivasi, the rest being Scheduled Castes (SCs) and Other Backward Classes (OBCs). ${ }^{7}$ Most villagers were subsistence farmers reliant on meagre landholdings (averaging 0.5-2 acres), and the sale of forest produce. Most households also participated in MGNREGA, a government livelihood scheme. $^{8}$

Using participant observation, conversations and interviews, the first author visited primary schools in the two villages and chatted with locals about education and their aspirations for the future. She also interviewed young people-school leavers and attendees-from neighbouring villages and the block, along with parents and teachers. All conversations were initiated in Hindi by the first author, a native speaker. Although respondents understood Hindi, they replied in the local dialect, so youth from neighbouring villages were occasionally involved as interpreters.

While the perspectives of local young people, along with parents and teachers, are privileged in this paper, further understanding of aage badhna was gleaned from

\footnotetext{
4 'Scheduled Tribe' (ST) is the Indian government's designation for adivasi groups (Galanter 1984).

5 Since 2004, Chhattisgarh has been home to a radical left movement, Naxalism (Pandita 2011), targeting remote districts where the state is perceived as absent. Naxalism was absent in the district of study.

6 Including Mid-day Meal Scheme (1995); 'para-teacher scheme' (2000); and Sarva Siksha Abhiyan (2004) to universalise primary schooling.

$7 \mathrm{SC}$ is the government classification for India's 'lowest' castes. OBC ranks above SC and ST, and below 'General castes'.

8 Since 2005, the Mahatma Gandhi National Rural Employment Guarantee Act guarantees 100 days' employment (e.g. road construction) to rural households.
} 
conversations with local carpenters, craftsmen, tailors, shopkeepers and small businessmen. The latter included livelihoods familiar to local youth: a roadside eatery, bicycle repair shop and local taxi service. The first author also interviewed youth attending vocational training courses and male students from elsewhere in rural Chhattisgarh, who were among the fortunate few to gain entry into a tribal hostel in New Delhi that prepares youth for civil service examinations. Interviews were also conducted with NGO workers involved in rural education and livelihoods, as well as government officials from local to national level.

In the paper, we alternate between the terms 'young people/person' and 'children/ child'. We understand, of course, that these categories constitute an over-simplification that neither captures the full differentiation of perspectives or 'agentive capacities' (Huijsmans et al. 2014, p. 168) of participants, nor gives due respect to age as a structuring social category (Ansell 2016, p. 320). While we mention ages or educational stages of participants, our objective is to unpack the relationship between education and aage badhna.

\section{Understanding aage badhna: Moving Forward and Falling Behind}

So what is aage badhna? This concept was used by young people and parents in discussions about what they want to be or do in future (for themselves or their children), and what was necessary for this to happen. It was also used by teachers in their exhortations to study, and by visiting government officials and NGO workers, who extolled the significance of schooling in facilitating forward movement.

The most successful outcome of aage badhna, most participants agreed, took the form of naukri: salaried, permanent employment. This concept, representing movement beyond reliance on land-based livelihoods and implying the opposite of manual labour (cf. Morarji 2016, p. 222), was associated with social status (linked with education-related success), spatial mobility (travelling or living beyond the village), and acquiring material things ('cement house', 'smartphone', 'motorcycle') and other 'freedoms' (Sen 1999) reflecting an improvement upon people's impoverished situation (Dost and Das 2021). What young people heard frequently-from schoolteachers, NGO visitors and other adults alike-was that the surest way to achieving aage badhna was through education. ${ }^{9}$

This concept was not unique to rural Chhattisgarh. Schoolteachers in rural north India, for example, describe one of their responsibilities as being to 'bring children forward' (Morarji 2016, p. 225). In her research on poverty, religion and identity construction amongst Class 11 Muslim girls in Old Delhi, Gupta (2015, pp. 84-86) observes how aage badhna was used to convey ideas of 'moving ahead' or 'not

\footnotetext{
9 While the relationship between aage badhna and schooling maps onto broader discourses of 'development' (Gupta 1998, pp. 11; 40; Hopper 2012), it is also pronounced within neoliberal discourses emphasising individual merit and competition (see Ganti 2014; Stahl 2015; Brown et al. 2011). In India, this relationship is linked to colonialism, which helped constitute schooling as a space privileging mental over manual labour (Balagopalan 2003, pp. 59-60).
} 
going backward'. While such observations form a small part of Gupta's broader research, the way in which aage badhna provides a sense of future direction is not dissimilar to how this notion was utilised in rural Chhattisgarh. Moving forward implied upward progress, both socially (in social/economic status) and spatially (from rural to urban). Backward movement conveyed the opposite: falling or being left behind (peechhe rehna). These notions also had an intergenerational dimension, with young people expected (and expecting) to make progress, not only in relation to peers, but also their parents.

Aage badhna was inextricably associated with aspirations engendered by education. Several young people asserted that schooling was 'most important' for 'getting ahead'. These aspirations were relationally produced (Huijsmans 2016) in dialogue with parental expectations as well as dominant discourses communicated within school. As Radhika explained, 'When [young] educated people talk to friends, they say things like, "I'll fulfil my father's dreams," or "if I do this my mother will be so happy"- and so they maintain their goal in life.' Teachers also encouraged young people to 'think about what gift we can give our mother and father,' suggesting that studying and 'getting good marks' will make their parents happy.

To illustrate parental roles further, Radhika's mother, a Mitanin, or low-ranking village health worker, told the first author that although Mitanins did not need to be ' 12 th pass' when she was selected, completing school had given her the confidence to engage with the community, allowing her to become a health worker. She was the first in her family to go so far in her studies. She also expressed concerns about her children's schooling, and the possibility that they might 'fall behind' if they did not study properly, not only in relation to her, but also losing out on future jobs. For these reasons she kept a close eye on her children's education, reminding them about the importance of studying, and assisting the youngest of her four daughters daily with schoolwork.

Few adivasi parents assisted their children in homework-largely because of perceptions around their lack of 'educated knowledge', given that most were illiterate or semi-literate. While this impeded their ability or confidence to help with schoolwork, it did not deter them from supporting their children's education (cf. Balagopalan 2003, p. 59). Indeed, most adivasi parents expressed similar views to Radhika's mother about the importance of schooling in facilitating forward movement, encouraging their children to attend school and articulating concerns that they would 'fall behind' their peers.

Take Parvati, a 6-year-old adivasi girl who lives a few houses away from Radhika. Despite being enrolled in Class 2, Parvati had barely attended a day of school, situated a 5-min walk from her home. She would cling to her parents and cry, refusing to leave home. In order to persuade Parvati to attend, her father (Class 5 educated) spent the first fortnight of the school year sitting next to her in class, missing out on his work as a village mason, helping her write the Hindi alphabet on a hand-held slate. Such efforts were unusual: most parents would not pass up opportunities to earn; instead, they responded to their children's resistance to schooling with bribes of sweets or threats of a beating. Parvati's father's actions reflected his anxiety about her future, along with his regret about not sending her to the Anganwadi, a local 
childcare centre attended by pre-school children. ${ }^{10} \mathrm{He}$ was worried, he said, that if his daughter does not become educated, she will fall behind other children.

The reluctance to attend school was uncommon later in primary school: while some children were found 'loafing about', or missed school to attend weddings or festivals, the majority attended school relatively regularly, acknowledging-in conversations with the first author-that education was 'important for aage badhna'; it will help you 'get ahead' and 'become successful'. Such sentiments carried on into secondary school, with a 14-year-old Class 9 boy reporting that 'when you study, your future increases... you can dream about doing anything.' These views were undoubtedly propagated through exhortations about 'working hard' that children heard at school or at home. They also revolve around broader, 'common sense' discourses, outlined above, about education being a 'fundamental social good', with potential to facilitate 'forward movement' and provide opportunities for a better future (Sen 1999).

The hopes that parents invested in schooling were a relatively recent phenomenon. In conversations with the first author, for example, Parvati's father compared her situation to his own childhood, describing his parents' ambivalent attitude towards school. This was a period (1980s-1990s) when formal education was neither compulsory nor thought to be particularly useful for young villagers, whose 'future' was inevitably rural-based. While basic literacy was considered somewhat useful, school attendance rates were low (see Froerer 2012). Parvati's father didn't worry too much about the future when he was young, he explained; like other young people, he took it for granted that it would be very similar to his present, underpinned by livelihoods revolving around subsistence agriculture. To this end, he recalls how his parentsalong with those of most of his peers-terminated his education after Class 5, considering anything beyond this to be useless.

These reflections show how local concerns about the possibility of 'falling behind' have, over the past generation, evolved in conjunction with the powerful discourses underpinning the transformative potential of schooling (Drèze and Sen 2014). ${ }^{11}$ Thanks in part to the increasing visibility of campaigns like the Anganwadi programme, along with Right to Education (RTE) legislation (2010) guaranteeing free primary education, parents and children have come to view education quite differently. ${ }^{12}$ With this has come a corresponding shift in views on the role of education in facilitating aage badhna.

Such concerns, in turn, have been informed by increased anxieties around landbased livelihoods. Owing to population increase, fewer young people will have

\footnotetext{
10 Since 1975, Anganwadi centres have provided nutrition, healthcare and educational activities in (especially) rural India. One of their objectives is preparing children for the discipline required for formal education.

11 While such discourses took shape during colonial rule, since independence India's education activities were related to its modernisation agenda and drive for economic liberalisation (Kumar 2015; Hopkins and Sriprakash 2015; Vasavi 2003). Many current initiatives were spearheaded by pressure from international campaigns and other 'education for all' schemes (NUEPA 2014, p. xvii).

12 Our intention is not to analyse aspirational shifts following RTE and other schemes; nor is it to map intergenerational changes regarding the legitimacy given to education and desires for aage badhna. It is simply to highlight legislation affecting the perceived utility of education, and how perceptions have shifted over one generation.
} 
sufficient land to support their families (cf. Froerer 2011). It was partly for such reasons that, provided they had 'the mind to study', parents tended to support their children's education. Any possibility of acquiring jobs promising future security and 'forward movement' independent of land-based livelihoods, they reasoned, could not be ignored.

For parents, then, it was its potential for facilitating the kind of aage badhna represented most notably by naukri that underpinned the value and continuing investment in schooling. These were particularly important aspirations for marginalised rural adivasis, whose structural disadvantages have historically prevented them from benefitting from school education (Balagopalan and Subrahmanian 2003). Exclusion from schooling, in contrast, meant losing out on opportunities that would lead to this kind of aage badhna. It is for such reasons that both Parvati's father and Radhika's mother were so concerned about their children's educational engagement.

As highlighted above, views regarding the intrinsic benefits of schooling and disadvantages of 'school-less-ness' (Jayaraj and Subramanian 2007, p. 188) resonate with the aforementioned discourses promoted by Sen (1999), Drèze and Sen (2014) and others. They also exemplify the 'relational dimension' (Huijsmans et al. 2016) of aspiration formation, whereby young people's aspirations for aage badhna are shaped in relation to peers and through interaction with parents' concerns. As we shall see below, however, such ideas are also shaped by local understandings of forward movement and embedded within broader conditions of rural marginality - at risk of being exacerbated by 'falling behind'. It is partly to mitigate such risks that local people remain attached to education, even in their awareness of the 'improbability' that education will lead to aage badhna (Jakimow 2016). People identify viable alternatives that continue to be informed by education, thereby mitigating the potential 'cruelty' inherent in its transformative potential (Berlant 2011). This is a subject that we consider further below.

\section{Forward Movement and the Role of Education}

To be clear, local people were aware that school education could not guarantee the kind of forward movement that they sought (the pinnacle of which was naukri). While there were several examples of rural young people who had completed secondary education, and even a handful who had gone to college, few of these had resulted in employment. Part of the reason for this was related to their structural disadvantages, compounded by the fact that there are simply not enough opportunities for naukri to match rising education levels in India, particularly amongst disadvantaged groups, resulting in high levels of 'educated unemployment' (Jeffrey 2010). ${ }^{13}$ Against this backdrop, it was not uncommon for a college graduate to return to the

\footnotetext{
13 Although a global phenomenon, in India this relates to liberalisation processes leading to rapid economic growth that favours better-educated urban middle classes. Existing jobs invariably go to higherclass young people with superior qualifications (see Kumar 2015; Corbridge et al. 2013).
} 
village, engaging in 'timepass' (Jeffrey 2010) whilst clinging to the idea that their education will translate into that coveted naukri.

Why do marginalised people remain attached to the transformative potential of education, in spite of the known obstacles impeding forward movement? And why does education continue to shape young people's aspirations beyond school? Here, we return briefly to Berlant's notion of 'cruel optimism', constituted as the 'condition of maintaining an attachment to a significantly problematic object' (2011, p. 24). As intimated above, in rural Chhattisgarh, this attachment revolves around the 'better future' promised by education (cf. Jakimow 2016). To believe in the idea that education will actually lead to this kind of future, in spite of existing structural constraints and the real possibility of failure, is thus a form of 'cruel optimism', becoming an obstacle to the kind of future 'flourishing' (Berlant 2011, p. 1) that is manifested in alternative and more viable pathways of forward movement that we outline below.

Part of the reason for this ongoing attachment to schooling, we suggest, is that education can actually lead to aage badhna and a secure future (naukri), evidenced by the occasional success story like the female teacher in Ashapur, or the few young men in nearby villages who gained entry to the police or army. Very few young people, of course, will go on to achieve this kind of 'forward movement'. As Morarji (2016, p. 236) observes, the (problematic) promises embedded within the education system simply 'fail to accommodate the range of ambiguities and negotiations' rooted in historical conditions of poverty, that rural young people experience (Drèze and Sen 2014). Notwithstanding these realities, the fact that there was a possibility for aage badhna through schooling continued to propel parental support and young people's aspirations for a better future. This was seen, for example, in the kind of investment that people like Parvati's father and Radhika's mother put into their children's education. Without such an investment, more desirable possibilities for a different future would be foreclosed.

The consequences of this 'almost impossibility', then, represent one way of thinking constructively about marginalised rural young people's continuing attachments for something that, in Jakimow's (2016, p. 21) words, is not 'objectively realizable' for most. While the negative effect of such attachments on the aspirations of disadvantaged youth have been considered more implicitly elsewhere in rural India (Morarji 2016; Morrow 2013; Balagopalan and Subrahmanian 2003), what has been less substantively discussed are the ways in which marginalised people and their parents seek accessibly viable pathways for aage badhna. And what is interesting is how alternative ideas of 'forward movement' remain anchored in schooling, even when education fails to lead to that coveted naukri.

Indeed, it was precisely because there was no guarantee that education would lead to naukri that both parents and young people remained realistic about the limitations of schooling, approaching alternative and more accessible pathways to aage badhna very pragmatically and-importantly_in relation to local ideas of success. For example, two boys who lived in Radhika's village, Jiten, a 14-year-old irregular school-attendee, and Naresh, a 16-year-old dropout, distinguished between different kinds of forward movement. Without education, they insisted, 'there is still a chance of moving forward', but only in two professions: masonry or driving. There were a 
few examples of young men in both villages who, having left school after Class 5, earned a steady income through driving, and even a primary schoolteacher who supplemented his income through running a local taxi service.

While masonry and driving were inferior to naukri, they were considered respectable alternatives to manual or agricultural labour, enabling young men to 'move forward' and one day even become highly paid contractors or transporters. In Naresh's words, 'as a labourer, you just stay at the same level,' which, in addition to being 'below' the jobs of mason or driver, was also 'quite boring.' In contrast to driving, Jiten and Naresh believed that the possibility of aage badhna was greater for a mason: although he has to work harder and might initially earn less than a driver, they described, he has the opportunity to engage in more skilful and challenging projects. A typical mason has completed primary school and then learns his trade from an experienced mason. If he closely observes the work of a contractor while serving under him, he can even take on contractual work and eventually manage projects on his own. We return to Jiten and Naresh in the final section, when we discuss how these young men reflect on the 'relational' dimension underpinning the distinction to which alternative forms of aage badhna give rise.

Owing to the traditional gender division of labour, occupations like driving and masonry were not feasible for girls. Upon leaving school (whatever their level or pass-mark), most girls assisted their parents at home and in the fields, occasionally participating in MGNREGA work as they awaited their marriages to be arranged. Some girls (mainly Christian adivasis; see Froerer 2012) sought work through different networks (like the Catholic Church) as domestic helpers elsewhere in India, enabling them to contribute toward the cost of their impending marriage, which usually took place 2-3 years after their schooling. It was more common, however, for girls to pursue some kind of vocational training (usually computing or tailoring) in a neighbouring district.

While most local girls spoke of their desire to study further, they were aware that marriage to a 'good man' with a regular income represented the most likely possibility for aage badhna. ${ }^{14}$ For example, a 17-year-old female dropout ('Class 9 fail') described how she wanted to own a village shop selling household items 'with two fridges for cold drinks, to have in the heat.' Asked how she would acquire the resources needed to set up the shop, she responded that she could either sell her family land or-pragmatically - marry a man who already owned a shop. Having 'at least' a middle school education, in addition to vocational qualifications, was believed to increase the possibility of receiving a marriage proposal from such a man (cf. Balagopalan and Subrahmanian 2003, p. 51). Another example is 18-year-old Chandrabati from a neighbouring village, whose parents quashed her aspirations to go to college in the belief that marriage would offer her more possibilities for aage badhna. Chandrabati convinced them to allow her to undertake a tailoring course at a local vocational college, reasoning that this would enhance her marriageability.

\footnotetext{
14 Marriage is a recognised form of social mobility for girls across India (see Rao 2010; Morrow 2013), steeped in patriarchal practices related to son preference and gendered divisions of labour (Subrahmanian 2005).
} 
Shortly after she completed this year-long training, her marriage was arranged to a respectable man who was himself an established tailor.

In short, while education was considered necessary to access the coveted naukri, young people recognised that some form of aage badhna was possible even without extensive education - through masonry, driving, or marriage - all of which were juxtaposed in relation to peechhe rehna (falling behind). Embedded within locally valued alternatives to the more prestigious naukri, these kinds of aage badhna nonetheless represented a better future than the low-status livelihoods of their parents, enabling young people to move forward in relation to the previous generation.

\section{Education and the Narrowing of Aspirations}

However, despite the existence of a few alternative paths to forward movement, education continued to be seen as enabling a wider range of opportunities for aage badhna: it was the means through which future marginality and impoverishment could be avoided (cf. Jakimow 2016, p. 17). This came out in conversations with Jiten and Naresh, who plainly asserted that with more years in education, "your future increases; you can do a whole lot'. Such sentiments were also articulated by Radhika who, as we saw at the beginning of this paper, noted that the educated villager can 'do anything' and 'become someone' embodying forward movement in multiple dimensions. Education symbolised boundless intellectual growth to youth like Jiten, Naresh and Radhika, all of whom described the 'development of the mind' itself as a form of aage badhna.

Moreover, education could enable villagers to attain these various aspirations while remaining in the village. This meant a great deal to most adivasi children who aspired to continue living in the village close to their family and community. When asked to draw a picture of himself as an adult, Mahesh, a 10-year-old primary school student, drew himself as a schoolteacher in his own village, earning enough, he said, 'to take care of my family'. Seema, a 14-year-old in Class 9, said her dream was to become a police officer so that she could stop her fellow villagers from drinking alcohol. As children saw it, opportunities for wage labour, in contrast to education-related occupations, often involved some form of temporary migration. Jiten and Naresh both knew young migrants from their village who worked on urban building sites or brick kilns. Such livelihoods provided moderate earnings, but were considered 'hard work', demanding months at a time away from home and viewed as potentially dangerous, with no guarantee of long-term security.

What is interesting is that although the possibilities opened up through education were described by children and parents as seemingly limitless (your 'future increases'; 'you can do anything'), young people's education-related aspirations revolved around a relatively narrow set of occupations. This became evident when they were asked about what they saw themselves doing in future. Their responses were most often becoming a teacher, nurse, police officer or militaryrepresenting the four most accessible forms of 'naukri' available locally. Images representing these occupations were scattered through primary school textbooks. Importantly, such occupations also mapped onto ideas of material progress. In 
the two study villages, for example, the three largest pukka homes (made of red bricks as opposed to mud) belonged to a family of teachers, police officers, and the Sarpanch (village headman).

As outlined above, however, this narrowing of young people's aspirations to a somewhat limited set of unattainable occupations does not always lead to the kind of 'cruel' outcome discussed by Jakimow (2016). While education (and education-related aspirations, in the form of naukri) remains the ideal to which young people aspire, they are also quick to adjust (and broaden) their aspirations to more accessibly viable futures. We saw this in the example of Jiten and Naresh.

This narrow exposure to four occupations was compounded by the fact that primary and middle schoolteachers gave little attention to children's aspirations or to their future livelihoods. Beyond the regular reminders that children 'must study', or the verbal reprimand of children who failed to do so, the first author observed no occasion where teachers discussed occupational pathways with pupils. In a conversation about why teachers didn't incorporate more such discussion in the classroom, a male primary teacher explained, 'Here we have schools at three levels-primary, middle and secondary. Our job is to ensure that children are taught the basics well-maths, Hindi, English—so that they are ready for middle and secondary school.' He also implied that the task of preparing children for their future lies with the children themselves, not with teachers. While teachers agreed that their broader pedagogical role was to inculcate knowledge that would help them succeed in 'becoming someone', they felt the chances of adivasi children achieving their aspirations were low, and so their everyday priority was to ensure that young people completed written exercises and scored adequately in exams.

School, in other words, was both transformative and limiting: it enhanced young people's aspirations for aage badhna, promising a future through sentiments conveyed within the kind of discourses that entreated children to 'work hard' so that they could 'become someone'; but it also limited what young people could aspire for, by virtue of the narrow range of occupations described in school and through lack of discussion about how they could act upon these aspirations.

Young people were, of course, aware of the existence of other occupations, particularly those accessible locally (including shopkeepers, tailors, carpenters). Additionally, there were a number of locals who served in non-permanent government posts, along with NGO workers and door-to-door salesmen, who embodied 'forward movement' in the various dimensions mentioned above. While some of these occupations were better paid than permanent government posts, they did not have the same status or perceived security as the four occupations classified as naukri. Importantly, they were never mentioned by young people as possible livelihood options, and therefore remained invisible in the school context, undervalued by the curriculum and unacknowledged by parents and children, whose enthusiasm for the same four occupations was expressed from the first year of primary school.

Young people did occasionally make reference to professionals whom they saw on television or smartphones: singers, politicians or detectives. But these careers were usually deemed to be inaccessible or 'too distant' to aspire for, with stories 
on screen presumed to be fictional. In this way, children were left to construct their aspirations around those few occupations that were visible locally.

It was only when (if) children from the village entered secondary school in the block capital that they began to learn about a broader range of occupations, such as the urban engineer or civil servant, and (importantly) the educational trajectory necessary to access these occupations. ${ }^{15}$ As they progressed through school, in other words, young people were gradually exposed to new opportunities and ideas of what it means to 'move forward'. For example, Raj, a 23-year-old unemployed youth from a neighbouring village, informed the first author that it was only while studying for his bachelor's degree in the block college that he became aware of the range of government jobs available, beyond the four he was familiar with in school—although he was no more confident that he would be able to acquire any of them.

Like Raj, secondary school children usually recognised that formal occupations were difficult to acquire for people 'like them': marginalised rural adivasis. While education (and education-related aspirations) was the ideal to which young people aspired, like Jiten, Naresh and Chandrabati, they were quick to adjust (and broaden) their aspirations to more accessible, locally-relevant futures.

As we can see from this discussion, one of the issues underpinning people's pragmatism about the kind of aage badhna supposedly made possible by schooling was related to lack of information of livelihood possibilities beyond those locally visible. Given that knowledge of only a few occupations representing forward movement was acquired through education, and bearing in mind that both young people and parents were pragmatic about the need for alternative livelihoods, why, then, did education continue to shape people's ideas for aage badhna?

\section{Aage badhna and the Relational Value of Education}

Part of the reason, we suggest, was related to the fear of 'falling behind'. As intimated above, education not only served as a vehicle or process through which future forms of aage badhna could be acquired, but also represented a form of aage badhna itself: a process of intellectual growth, as well as an aspiration or status achievement contrasting directly with peechhe rehna and 'backwardness'. The handful of success cases of naukri in the surrounding villages demonstrated that this was very much possible. As we show in this final section, it is this possibility, along with the personal transformation brought about during education itself, that drove local people's continued belief in the value of education.

Bourdieu's (1984, 1989) work is pertinent to understanding the correlation between education and aage badhna, particularly in terms of the different kinds of capital that represent forms of forward movement. As is well known, Bourdieu extended traditional notions of 'capital' that privileged material and economic forms of wealth by foregrounding social capital-useful relationships, connections and

\footnotetext{
15 Historically, such professions have represented financial security and social status for the urban middle class (Donner 2011), seeping into peri-urban areas and villages relatively recently.
} 
networks - along with other forms of cultural knowledge that confer social distinction (cf. Calhoun et al. 1993). He also highlighted the role played by education in accessing these different forms of capital, which together provide crucial advantages in facilitating forward movement. In doing so, Bourdieu provided a means to examine how existing structural disadvantages impact upon marginalised young people's engagement with education, informing their aspirations and ability to get ahead.

In drawing on Bourdieu, we are not suggesting that important forms of capital can be easily or unproblematically acquired through education, particularly in contexts where schooling serves as a primary vehicle for the reproduction of social inequalities. ${ }^{16}$ But we find his framework to be useful in understanding how important forms of educational capital are acquired and valued, and the role these play in both perpetuating the 'cruel optimism' (Berlant 2011) that underpins education's transformative potential, and providing a means for an alternative future.

Let us unpack this further. In the words of a local NGO worker, schooling symbolised 'a ladder of forward movement' on which children are positioned the moment they enrol in Class 1 . As we saw with Parvati, the very fact of going to school constituted a valuable form of educational capital that contrasted with 'falling behind', an undesirable status that was risked by those who did not attend school. In addition to the status that merely stepping on that ladder bestowed, schooling provided children with important knowledge and skills (literacy and numeracy) which, while not sufficient in themselves to access naukri, were useful in assisting illiterate parents with their marketing, travel or banking needs, or with their applications for government benefits. Such skills, moreover, were considered to be helpful in facilitating access to alternative (non-naukri) forms of employment, such as driving or masonry, and in securing a good marriage proposal.

This kind of capital also assumed more behavioural forms. For example, Jiten and Naresh described how educated people were more disciplined because 'they pay more attention to keeping their children clean and do not wander around like an aimless vagabond.' They further suggested that with education, the mind became less preoccupied with immediate monetary needs and more focused on learning. Comparing manual labourers with educated individuals, Jiten explained that 'simple labourers won't be thinking... all they'll worry about is how much money will come, when will it come.' The one who studies, in contrast 'will of course think about what he's studying-he'll read the book, think about it, his worries will be focused on his studies.'

Morarji (2016, p. 233) makes similar observations about her north Indian participants, who reflect on how 'education changes things from within', engendering processes of 'self-improvement and personal transformation' (vikaas) (cf. Jakimow 2016). Morarji notes how this 'educated subject position' (ibid) was invariably

\footnotetext{
16 Indeed, Bourdieu's work, alongside the social reproduction discourse more generally, has been rightly criticised on a number of grounds, e.g. for downplaying individual agency and for the assumption that people will reproduce themselves in the manner of the generation before them (cf. Stahl 2015; Collins 2009). In respect of the latter, this implies that marginalised people, given their perceived inferior cultural capital, will remain decidedly disadvantaged, reproducing themselves and occupying the same marginalised social position as the generation before them.
} 
framed in relation to those who were uneducated: those bound, in other words, for a future of manual labour. Such observations also represent an interesting 'relational' dimension of education (cf. Huijsmans et al. 2016) that exemplifies what Balagopalan (2003, p. 59) describes as 'the symbolic distance that formal schooling creates from the world of manual labour.' Here, the latter is 'inferiorised' and constructed to be 'unworthy', particularly in relation to someone who is educated. This inferiorisation of manual labour is also linked to the civilising project that underpinned India's colonial education policies, which privileged elite classes and their 'potential' over lower class masses. ${ }^{17}$

Through such examples, we see how educational capital represents a status achievement (age badhna) that contrasts, in a seemingly binary fashion, with peecche rehna. While such notions appear to map onto dominant discourses in which education is deemed to be intrinsically beneficial (Sen 1999; Drèze and Sen 2014), here they are embedded within local ideas of distinction and constituted in a more complex and 'relational' manner (Huijsmans et al. 2016). For example, being 'educated' represents forward movement in relation to being 'illiterate' (anpar), and most people were in agreement that for reasons of literacy, education was fundamentally useful. However, there was no specific stage at which being educated was deemed to be 'enough' to ensure that one would not 'fall behind'. For some, a Class 8 or 9 education was enough to secure a good marriage; for others a minimum of Class 10 or 11 was required, while the dowry demanded by the groom's family was usually increased in proportion to his level of education. Equally, a Class 10 education may be insufficient to access a naukri, but was viewed as adequate for a job as a driver. While people remained uncertain about whether education would actually help them to move forward, there was no consensus about precisely when 'too much' education might jeopardise a child's chances. In other words, the value attached to education, and its role in facilitating aage badhna or preventing peechhe rehna, was distinguished in relation to specific aspirations (a good marriage proposal; naukri as opposed to masonry or manual labour) as well as in relation to others (peers, previous generations, or competitors for naukri).

In addition, the particular forms of capital conferred through education were considered necessary components for facilitating access to a further source of capital: namely, those relationships and social connections that enabled young people to avail of future opportunities to 'get ahead' (Bourdieu 1984). Socialising mainly with their peers locally, young people were limited in their ability to access social networks beyond the village. The different forms of capital gained through schooling, however, provided them with the confidence, language and etiquettes to make important social connections with outsiders. For example, the first author met a few adults who, having completed their education in villages similar to Ashapur and Icchapur, had left rural Chhattisgarh for educational or employment opportunities elsewhere. These individuals included a District Collector, two female teachers who were posted elsewhere in the district, several young men training for civil service

\footnotetext{
17 The fallout of such policies continues to be felt today, in the ongoing structural disadvantages related to their historical marginalisation (Balagopalan 2003, p. 59; cf. Vasavi 2003; Kumar 2015).
} 
exams in New Delhi's tribal hostel, and a security guard in Delhi who spent his free time learning how to start a business.

One thing these individuals agreed on was the importance of education in the way it empowered them to pursue a wider range of opportunities. One of the teachers who grew up in a village $15 \mathrm{~km}$ away from Ashapur, for example, narrated how she secured her appointment to a competitive teaching post only after initiating a conversation with the District Collector when the latter visited her village. Approaching such a high-ranking administrative official is unusual, and this teacher insisted that she would not have had the confidence to speak to the Collector, who agreed to intervene on her behalf, without first learning to overcome her 'timidity' during her primary school years.

To be clear, such forms of capital were often shaped by a supportive family member or other acquaintance who encouraged daily educational engagement. As evidenced in the examples of Radhika's mother or Parvati's father, a parent's own aspirations can also play an important part in supporting the educational aspirations of children. But most local parents do not get involved to this degree-mainly, as discussed earlier, because of their own lack of education. When the first author asked one parent what he hoped for his children, he replied matter-of-factly, 'if they wish to study, we will support them, and maybe they can get naukri. If not, then they will do manual labour. That is our thinking.' Indeed, while subscribing to the transformative potential of education and supporting their children in their educational and aspirational pursuits, parents remain pragmatic.

In short, the possibility of acquiring some kind of naukri presents itself only when a young person is in possession of the necessary forms of capital that derive from education. While naukri represents the most desirable form of education-based aage badhna, as we saw, education — and the accompanying capital—can also give rise to alternative and often more viable future trajectories. It is this understanding, compounded by the very real possibility of losing out on opportunities for a better future, that reinforced the central role of education in shaping aspirations for 'moving forward'.

\section{Conclusion}

Throughout this article, we have focused on how marginalised young people and their parents understand and navigate the complexities around aspirations for aage badhna. We have shown how young people's future orientations remain anchored in education, even when the most desirable possibilities of forward movement (naukri) have been eliminated. Drawing on and extending existing analyses that examined different outcomes and consequences arising when education-based aspirations are found to be 'all but impossible' (Jakimow 2016, p. 26; Berlant 2011), we demonstrated why education remains central to aspirations for forward movement-not because of the attachment to the 'almost impossibility' (Jakimow 2016, pp. 26-27) to get ahead, but because it proves to be productive in the (re)framing of accessibly viable futures. 
We have also seen how aspiration formation is fundamentally relational, manifested in the ways in which young people distinguish or set themselves apart from (or ahead of) others. This kind of distinction is constituted, in the first instance, through the status attached to being educated in contrast to being uneducated. As young people progress through (or drop out of) school, notions of forward and backward movement continue to be manifested in relative terms: the role of education in the acquisition of naukri sits alongside localised representations of aage badhna. The value attached to different educational achievements, moreover, is determined in relation to the context in which it is applied: marriage, masonry or manual labour. Thus any understanding of the ways in which rural young people's aspirations are formed relationally must take into account their structural positions of marginality.

To this end, more could have been said about the disadvantages that rural adivasis face, the neglect of aspiration-related issues in the content of education, the limited support provided by state and non-state organisations to expand employment opportunities for school graduates, and about the economic capital required by young people to get ahead. Equally, further consideration of the role played by (especially) secondary schoolteachers in preparing marginalised youth for the future would have contributed a deeper understanding of the role of schooling in shaping and attaining aspirations.

Notwithstanding the need for further research, we conclude with some important implications regarding both the relationality of aspiration formation, and the powerful discourses concerning the benefits of education. If education is aage badhna, and if aage badhna increasingly requires distinction from others-to acquire some form of naukri-then education in its current form cannot by itself lead to forward movement for everyone. For if everyone moves forward, then no one 'stands out'something that seems essential in the context of a rural economy in which opportunities for job acquisition are few and far between.

There is thus a contradiction between the transformative potential of education as a mass project aimed at providing substantive benefits, and the reality that not everyone can move forward through the opportunities made available by this mass project. The contradiction becomes all the more striking when we see that efforts to expand educational access in India over the decades have remained unaccompanied by comparable initiatives to expand job creation. In this respect, education can be construed as a 'cruel' project (Berlant 2011) encouraging aspirations for a particular kind of aage badhna that few rural youth can access.

However, if we apply a relational approach to aage badhna, then we can understand why education remains at the centre of aspirations for forward movement. If aage badhna is about growth in multiple dimensions (including but not only naukri), a relational approach becomes critical to understanding how young people distinguish themselves in contexts of deprivation, developing aspirations in relation to their current capabilities, and in relation to peers and parents, as they navigate their way towards a better future.

Funding Funding was provided by ESRC-DFID Raising Learning Outcomes in Education Systems (Grant No. ES/N01037X/1). 
Open Access This article is licensed under a Creative Commons Attribution 4.0 International License, which permits use, sharing, adaptation, distribution and reproduction in any medium or format, as long as you give appropriate credit to the original author(s) and the source, provide a link to the Creative Commons licence, and indicate if changes were made. The images or other third party material in this article are included in the article's Creative Commons licence, unless indicated otherwise in a credit line to the material. If material is not included in the article's Creative Commons licence and your intended use is not permitted by statutory regulation or exceeds the permitted use, you will need to obtain permission directly from the copyright holder. To view a copy of this licence, visit http://creativecommons.org/licen ses/by/4.0/.

\section{References}

Ansell, N. 2016. Age and Generation in the Service of Development? In Generationing Development: A Relational Approach to Children, Youth and Development, ed. R. Huijsmans, 315-330. London: Palgrave Macmillan.

Ansell, N., P. Froerer, R. Huijsmans, C. Dungey, A.C. Dost, and Piti. 2020. Educating 'Surplus Population': Uses and Abuses of Aspiration in the Rural Peripheries of a Globalising World. Fennia. https://doi.org/10.1057/s41287-020-00337-1.

Appadurai, A. 2004. The Capacity to Aspire: Culture and the Terms of Recognition. In Culture and Public Action, ed. V. Rao and M. Walton, 59-84. Stanford: Stanford University Press.

Balagopalan, S. 2003. 'Neither Suited for Home nor for the fields': Inclusion, Formal schooling and the Adivasi Child. IDS Bulletin 34 (1): 55-62.

Balagopalan, S. 2005. An Ideal School and the Schooled Ideal: Some Reflections On Educational Experiences at the Margins. In Educational regimes in contemporary India, ed. R. Chopra, and P. Jeffery, 83-98. New Delhi: Sage.

Balagopalan, S. 2014. Inhabiting 'Childhood': Children, Labour and Schooling in Postcolonial India. Basingstoke: Palgrave Macmillan.

Balagopalan, S., and R. Subrahmanian. 2003. Dalit and Adivasi Children in Schools: Some Preliminary Research Themes and Findings. IDS Bulletin 34 (1): 43-54.

Berlant, L. 2011. Cruel Optimism. Durham: Duke University Press.

Bourdieu, P. 1984. Distinction. London: Routledge.

Bourdieu, P. 1989. The State Nobility: Elite Schools in the Field of Power. London: Polity Press.

Brown, P., H. Lauder, and D. Ashton. 2011. The Global Auction: The Broken Promises of Education, Jobs and Incomes. Oxford: Oxford University Press.

Calhoun, C., E. LiPuma, and M. Postone (eds.). 1993. Bourdieu: Critical Perspectives. Chicago: University of Chicago Press.

Camfield, L. 2011. Editorial: Young Lives in Transition: From School to Adulthood? European Journal of Development Research 23 (5): 669-678.

Census of India. 2011. Registrar General of India, Ministry of Home Affairs, Government of India. New Delhi: Census of India.

Chopra, R., and P. Jeffery (eds.). 2005. Educational Regimes in Contemporary India. New Delhi: Sage.

Collins, J. 2009. Social Reproduction in Classrooms and Schools. Annual Review of Anthropology 38: 33-48.

Corbridge, S., J. Harriss, and C. Jeffrey. 2013. India Today: Economy, Politics and Society. Cambridge: Polity Press.

Donner, H. (ed.). 2011. Being Middle Class in India: A Way of Life. Abingdon: Routledge.

Dost, A.C., and M. Das. 2021. From Compulsion to the Freedom of Choice: Democratising Development Through Earth Architecture. In Another Way to Build: Re-viewing/Renewing Designs from the Community, ed. S. Mukherjee and A.S. Mukherji. Delhi: Routledge.

Drèze, J., and A. Sen. 2014. An Uncertain Glory: India and its Contradictions. London: Penguin.

Fischer, E. 2014. The Good Life: Aspiration, Dignity and The Anthropology of Wellbeing. Stanford: Stanford University Press.

Froerer, P. 2011. Education, Aspiration and Inequality in Central India. European Journal of Development Research 23 (5): 695-711.

Froerer, P. 2012. Learning, Livelihoods and Social Mobility: The Utility of Girls' Education in Chhattisgarh, Central India. Anthropology and Education Quarterly 43 (4): 344-357. 
Frye, M. 2012. Bright Futures in Malawi's New Dawn: Educational Aspirations as Assertions of Identity. American Journal of Sociology 117 (6): 1565-1624.

Galanter, M. 1984. Competing Equalities: Law and the Backward Classes of India. Berkeley: University of California Press.

Dreze, J., and A. Sen. 2014. An Uncertain Glory: India and its Contradictions. London: Palgrave.

Ganti, T. 2014. Neoliberalism. Annual Review of Anthropology 43: 89-104.

Gupta, A. 1998. Postcolonial Developments: Agriculture in the Making of Modern India. Durham: Duke University Press.

Gupta, L. 2015. Education, Poverty and Gender: Schooling Muslim Girls in India. New Delhi: Routledge. Hopkins, L., and A. Sriprakash. 2015. The Poor Child. London: Routledge.

Hopper, P. 2012. Understanding Development: Issues and Debates. London: Polity.

Huijsmans, R. (ed.). 2016. Generationing Development: A Relational Approach to Children, Youth and Development. London: Palgrave Macmillan.

Huijsmans, R., S. George, R. Gigengack, and S.J.T.M. Evers. 2014. Introduction. Theorising Age and Generation in Development: A Relational Approach. European Journal of Development Research 26 (2): 163-174.

Huijsmans, R., N. Ansell, and P. Froerer. 2020. Editorial Introduction: Development, young people, and the social production of aspirations. European Journal of Development Research. https://doi. org/10.1057/s41287-020-00337-1.

Ibrahim, S. 2011. Poverty, Aspirations and Wellbeing: Afraid to Aspire and Unable to Reach a Better Life-Voices from Egypt. Manchester: BWPI Working Paper.

Jakimow, T. 2016. Clinging to Hope Through Education: The Consequences of Hope for Rural Labourers in Telangana, India. Ethos 44 (1): 11-31.

Jayaraj, D., and S. Subramanian. 2007. Out of School and (Probably) in Work: Child Labour and Capability Deprivation in India. Journal of South Asian Development 2: 177-226.

Jeffrey, C. 2010. Timepass: Youth, Class and the Politics of Waiting in India. Palo Alto: Standford University Press.

Jha, J., and D. Jhingran. 2005. Elementary Education for the Poorest and Other Deprived Groups. Delhi: Manohar.

Kumar, K. 2015. Politics of Education in Colonial India. London: Routledge.

Majumdar, M., and J. Mooij. 2011. Education and Inequality in India: A Classroom View. London: Routledge.

Ministry of Human Resource Development, Government of India (MHRD GoI). 2020. https://www. education.gov.in

Morarji, K. 2016. Subjects of Development: Teachers, Parents, and Youth Negotiating Education in Rural North India. In Generationing Development: A Relational Approach to Children, Youth and Development, ed. R. Huijsmans, 221-242. London: Palgrave Macmillan.

Morrow, G. 2013. Whose Values? Young People's Aspirations and Experiences of Schooling in Andhra Pradesh, India. Children and Society 27: 25-269.

NUEPA. 2014. Education for All: Towards Quality with Equity. New Delhi: Ministry of Human Resource Development.

Pandita, R. 2011. Hello, Bastar: The Untold Story of India's Maoist Movement. Chennai: Westland (Tranquebar Press).

Rao, N. 2010. Aspiring for Distinction: Gendered Educational Choices in an Indian Village. Compare 40 (2): $167-183$.

Reserve Bank of India. 2013. Handbook of Statistics on the Indian Economy. Mumbai: India Printing Works.

Sarvalingam, A., and M. Sivakumar. 2004. A Study About Poverty, Health, Education and Human Deprivation in India. Erode: Chikkaih Naicker College: Department of Economics.

Sen, A. 1999. Development as Freedom. Oxford: Oxford Uuniversity Press.

Stahl, G. 2015. Identity, Neoliberalism and Aspiration: Educating White Working Class Boys. London: Routledge.

Subrahmanian, R. 2005. Gender Equality in Education: Definitions and Measurements. International Journal of Education Development 25: 395-407.

Vasavi, A.R. 2003. Schooling for a New Society? The Social and Political Bases of Education Deprivation in India. IDS Bulletin 34 (1): 72-80. 
Publisher's Note Springer Nature remains neutral with regard to jurisdictional claims in published maps and institutional affiliations. 